\title{
VOICES FROM SILICON VALLEY EXPOSE THE POLARIZATION OF KNOWLEDGE IN THE INFORMATION AGE
}

\author{
VOZES DO VALE DO SILÍCIO EXPÕEM A POLARIZAÇÃO DO CONHECIMENTO \\ NA ERA DA INFORMAÇÃO
}

\section{VOCES DEL VALLE DEL SILICIO EXPONEN LA POLARIZACIÓN DEL CONOCIMIENTO EN LA ERA DE LA INFORMACIÓN}

Rodrigo Moreno Marques ${ }^{1}$; Marta Macedo Kerr Pinheiro²

\begin{abstract}
The article is part of a research agenda that adopts the lenses of Political Economy to discuss the following question: what is the role of information and knowledge in the socioeconomic dynamics of the twenty-first century? Firstly, the article confronts two different theoretical perspectives: the cognitive capitalism and the polarization of knowledge approaches. Given the lack of agreement between these interpretations, the article also presents some results of an empirical investigation conducted in Silicon Valley (California), where semistructured interviews with local workers' representatives were adopted as an instrument of investigation. The voices of those who live the reality represented by the theories expose some contradictions in the local educational system, where the phenomenon of polarization of knowledge strengthens socioeconomic inequalities.
\end{abstract}

KEYWORDS: Polarization of knowledge. Silicon Valley. Education. Cognitive capitalism.

RESUMO

O artigo está inserido em uma agenda de pesquisa que adota as lentes da Economia Política para discutir a seguinte questão: qual é o papel da informação e do conhecimento nas dinâmicas socioeconômicas do século XXI? Primeiramente, o artigo confronta duas perspectivas teóricas diferentes, a saber, as abordagens do capitalismo cognitivo e da polarização do conhecimento. Dada a falta de acordo entre essas interpretações, o artigo também apresenta alguns resultados de uma investigação empírica conduzida no Vale do Silício (Califórnia), onde entrevistas semiestruturadas com representantes dos trabalhadores locais foram empregadas como instrumento de investigação. As vozes daqueles que vivem a realidade representada pelas teorias expõem algumas contradições no sistema de educação local, onde o fenômeno da polarização do conhecimento expande desigualdades socioeconômicas.

PALAVRAS-CHAVE: Polarização do conhecimento. Vale do Silício. Educação. Capitalismo cognitivo.

\footnotetext{
${ }^{1}$ Doutor em Ciência da Informação - Escola de Ciência da Informação da Universidade Federal de Minas Gerais (ECI/UFMG). Professor e pesquisador da Universidade FUMEC - Belo Horizonte, MG - Brasil. E-mail: rodrigomorenomarques@yahoo.com.br

2 Doutorado em Ciência da Informação - IBICT/CNPq-ECO-UFRJ (2001) com período sanduíche em Sociologie pelo Centre d'Études des Mouvements Sociaux (1999).

Pós-doutorado em Ciência da Informação e da Comunicação pela Universidade Paul Sabatier/IUT/Toulouse III (2008). Professora e pesquisadora da Universidade FUMEC FUMEC - Belo Horizonte, MG - Brasil. E-mail: martakerr@gmail.com
}

Submetido em: 09/07/2018 - Aceito em: 23/04/2019

(C) ETD- Educação Temática Digital Campinas, SP $\quad$ v.21 n.4 $\quad$ p.960-978 $\quad$ out./dez. 2019 


\section{RESUMEN}

El artículo es parte de una agenda de investigación que adopta las lentes de la Economía Política para discutir la siguiente cuestión: ¿cuál es el papel de la información y del conocimiento en las dinámicas socioeconómicas del siglo XXI? En primer lugar, el artículo confronta dos perspectivas teóricas diferentes: los enfoques del capitalismo cognitivo y de la polarización del conocimiento. Dada la falta de acuerdo entre estas interpretaciones, el artículo también presenta algunos resultados de una investigación empírica conducida en el Valle del Silicio (California), donde entrevistas semiestructuradas con representantes de los trabajadores locales fueron empleadas como instrumento de investigación. Las voces de aquellos que viven la realidad representada por las teorías exponen algunas contradicciones en el sistema de educación local, donde el fenómeno de la polarización del conocimiento expande desigualdades socioeconómicas.

PALABRAS-CLAVE: Polarización del conocimiento. Valle del Silicio. Educación. Capitalismo cognitivo

\section{INTRODUCTION}

One question challenges society nowadays: What is the role of information and knowledge in the socioeconomic dynamics of the twenty-first century? To face this problem, this article adopts the lenses of Political Economy to shed light on this complex problem.

Firstly, the article confronts two different theoretical approaches: the cognitive capitalism and the polarization of knowledge frameworks. However, the new frontiers of the Political Economy do not reveal a single path to apprehend the dynamics of society in the socalled information age. There is no consensus about some fundamental phenomena of our times, such as the interrelation between knowledge and creation of value, as well as the processes of creation of value within the realm of intangible commodities. Controversies also dominate the debate on the social relations of production that rule the sphere of immaterial goods. The lack of agreement is a stimulus to cross the limits of the theoretical universe and confront the academic discourses with the voices of those who live the reality represented by the theories.

Therefore, after the theoretical discussion, the article presents the results of an empirical research conducted in Silicon Valley (California, United States), where semistructured interviews with representatives of the local workers were adopted as an instrument of investigation.

The selection of Silicon Valley, located on San Francisco Bay, as the locus of the research, is due to the fact that the region is historically related to the development of innovative knowledge, scientific advances, and intellectual work. Moulier Boutang (2011a, p. 6) says that "it was in Silicon Valley that the new world economy was being forged, the new historical and contemporary capitalism". As the author states, the entrepreneurs of the region have a significant role in this new economy, since "they have discovered and invented the new form of value" (MOULIER BOUTANG, 2011a, p. 49). Over the past decades, with the outsourcing of the production plants to low-wage countries, there has been an economic restructuring in Silicon Valley. Instead of producing hardware, the local companies 
increasingly invest in conceiving products and web applications, while the physical production plants are outsourced and offshored.

In fact, for decades Silicon Valley has been a cradle of disruptive technological advances and one of the most innovative regions of the world. Nevertheless, one who tries to grasp the essence of Silicon Valley's reality must avoid falling into the traps of technological determinism. The confrontation of the academic discourses with the voices of those who live the reality represented by the theories suggests that the cognitive capitalism approach disregards some fundamental contradictions of contemporary society. As the respondents reveal, within the decaying and uneven Silicon Valley's education system, the polarization of knowledge becomes a phenomenon that strengthens socioeconomic inequalities.

\section{COGNITIVE CAPITALISM}

In order to present some central arguments of the cognitive capitalist framework, this session focus on the works of the French economist Yan Moulier Boutang (2003, 2011a, 2011b, 2012). After briefly presenting his theory, we point out some blind spots of his approach.

Cognitive capitalism has strong affinities with autonomism and post-operaism, two schools of thought whose authors, although tend to endorse the idea of general intellect proposed by Marx in the Grundrisse (MARX, 1987), consider the classical Political Economy theories, including the Marxian and Smithian conceptions, outdated frameworks which are useless to understand what it is going on in our times. ${ }^{3}$

The central idea of cognitive capitalism approach is that there is an ongoing radical and structural mutation in the capitalist mode of production. Within this new paradigm, the socioeconomic relations born during the industrial revolution in the $18^{\text {th }}$ century no longer describe the current reality in which the creation of value is supposed to be mainly related to immaterial goods, such as information and knowledge, instead of the old material commodities of the industrial age.

Moulier-Boutang proposes a new Political Economy that, albeit still using the classical categories like labor, value, and capital, presents some controversial propositions.

\footnotetext{
${ }^{3}$ Other examples of this school of thought are: LAZZARATO, Maurizio. Immaterial labour. In: VIRNO, Paolo, HARDT, Michael (orgs.). Radical thought in Italy. Minneapolis: University of Minnesota Press, 1996; GORZ, André. O Imaterial: Conhecimento, Valor e Capital, São Paulo: Annablume, 2005; VERCELLONE, Carlo. From Formal Subsumption to General Intellect: Elements for a Marxist Reading of the Thesis of Cognitive Capitalism, Historical Materialism, v. 15, n. 1, 2007; NEGRI, Antônio. Reflections on empire. Cambridge: Polity, 2008.
}

(C) ETD-Educação Temática Digital Campinas, SP $\quad$ v.21 n.4 $\quad$ p.960-978 $\quad$ out./dez. 2019 
From Moulier Boutang's perspective, cognitive capitalism is a new system of accumulation based on transformations that change the form of value, the substance of value and the surplus value. In this scenario, accumulation is supposed to come from knowledge, creativity and from some forms of immaterial investment. The "material labour does not disappear, but loses its central role as a strategic asset" (MOULIER BOUTANG, 2011a, p. 51), and the "hegemony of the paradigm of industrial labour and manual labour power" is "coming to an end" (MOULIER BOUTANG, 2011a, p. 53).

In cognitive capitalism, the externalities ${ }^{4}$ play an increasingly important economic role. The capture of positive externalities is considered the primary source of value. To illustrate the idea of a positive externality, the metaphor of the beekeeping is taken. The bees produce, in addition to honey and wax, a much more important positive externality which is the pollination of plants and, consequently, make human food production possible. From this perspective, our society is considered a digitally instrumented pollen society (MOULIER BOUTANG, 2011a, 2011b, 2012).

The author also states that what characterizes cognitive capitalism is not uniquely the emergence of the immaterial, since this phenomenon was also present in the industrial capitalism. To explain some of the main aspects of cognitive capitalism, the intangible goods are classified as "immaterials" of type 1 and type 2 . Knowledge which can be codified in the form of oral language, writing, and digital media is included in the immaterials of the first type. In this case, the intellectual property rights can be fully applied, such as patents, brands, copyrights and certificates of origin. The immaterials of the second type are the intangible goods that cannot be codified or are difficult to be codified, such as non-externalizable tacit knowledge, the ability to interpret data and symbols, confidence, cooperation, care, technique, and talent. The immaterials of type 2 are also associated with the capacities of contextualization, learning, and intelligence, which allow workers to find answers to questions that cannot be previously predicted (MOULIER BOUTANG, 2011b, 2012).

Although Moulier Boutang (2011a, p. 34) recognizes that the accumulation of profit requires investment in education and training, the author also claims, in a different direction, that in cognitive capitalism, the main source of value is the exploration of intangibles of the second type, instead of knowledge reified in commodities and sold as classical goods and services (MOULIER BOUTANG, 2011b). The appropriation of positive externalities, as well as of immaterial activities of type 2 , can be accomplished through technologies created to track cognitive activities developed in networks, such as search engines, like Google, and Web 2.0

\footnotetext{
${ }^{4}$ According to the author, the production of an externality occurs when any transaction (not necessarily a mercantile one) between two agents results in an effect on other agents that were not originally involved.
}

(C) ETD-Educação Temática Digital Campinas, SP $\quad$ v.21 n.4 $\quad$ p.960-978 out./dez. 2019 
tools. This trend reflects, as the author explains, a new logic of value and a new logic of economy.

Cognitive capitalism mainly explores the inventive force instead of the old labor force, and the value of knowledge is supposed to depend on the level of cooperation between brains interconnected in networks.

If the core of the value to be extracted is based on intelligent, inventive and innovative labour, and if the latter mobilises the cooperation of brains in networks, then capturing positive externalities becomes the number one problem of value. In other words, what needs to be uncovered and addressed is work done outside working hours, and implicit knowledge, and capacities for contextualization (MOULIER BOUTANG, 2011a, p. 55).

As maintained by the author, the Internet, as well as information and communication technologies, provides an unhindered network, without barriers to the circulation of information and knowledge, allowing the cooperative mediation of users. The World Wide Web is considered the main element of the world of common goods, which is supposed to be much more productive than the world of commercial exchanges. The web is also described as an instrument that enables a new and revolutionary economic logic based on a gift economy. The examples presented by the author are the production of open source operating systems like Linux, the free online encyclopedia Wikipedia, and the exchange of files through peer-topeer communities and social networks (MOULIER BOUTANG, 2011a, 2011b, 2012).

Because cognitive capitalism is based on the appropriation of the collective intelligence that emerges in interactive networks and needs to accumulate intellectual capital, it requires the human activity of pollination; that is, necessitates access to common goods available for free in non-commercial activities, even if this necessary freedom clashes with the restricting logic of intellectual property rights (MOULIER BOUTANG, 2011a, 2011b).

Furthermore, according to this theory, it is impossible for capital to expropriate worker's collective knowledge since knowledge is supposed to flow freely through the new technological platforms (MOULIER BOUTANG, 2003). The Internet is described as "the new global common good of the collective intelligence" (MOULIER BOUTANG, 2011a, p. 53) within a world of information and knowledge-goods "no longer characterized by scarcity" (MOULIER BOUTANG, 2011a, pp. 65-66). In other words, "the cognitive division of labour that is increasingly being practiced in learning companies and on the Internet is a society in which knowledge and culture are disseminated widely and shared, and where this raw material becomes abundant" (MOULIER BOUTANG, 2011a, p. 68). This supposed open character of the Internet and the belief in an unlimited flow of knowledge inside and outside of the "learning companies" bring the possibility of the emancipation of workers. In this sense, the knowledge worker becomes

(C) ETD- Educação Temática Digital Campinas, SP $\quad$ v.21 n.4 $\quad$ p.960-978 $\quad$ out./dez. 2019 
conscious of his role in the formation of value and, unlike the industrial salaried proletariat, he possesses, in his knowledge and in his skills, a production instrument that cannot be expropriated. The predator company becomes, in its knowledge, a prey (MOULIER BOUTANG, 2003, p. 44, translated from Portuguese).

From our point of view, the theory of cognitive capitalism flirts with technological determinism since it takes the advances of technology as elements that revolutionize society, although no explicit political project drives this hypothetical transformation. More specifically, it echoes a dominant kind of contemporary technological determinism since the flow of information and knowledge through the Web is supposed to be stimulating a revolution in the socioeconomic dynamics, although no conscious political action guides this alleged radical change.

Marx (1996) sheds light on this obscure discussion about the role of technology, science, and knowledge in capitalist social relations. Analyzing the great technological advances of his time, especially in the production processes, he did not establish a direct correlation between technological innovations and the emancipation of the oppressed classes. The Marxian works do not present the advances in technology as the key to overcoming capitalism. In a different direction, Marx stresses the decisive role of the contradictions between productive forces and social relations of production. Nevertheless, the mere existence of contradictions is not enough. According to him, the revolutionary transformations of humankind require class struggle and political action.

In agreement with the ideas of Antunes (2009) and Amorim (2009), our perspective advocates that the discourses of cognitive capitalism present the technical aspects of the productive forces as the elements that drive radical transformations of society, whereas the social relations of production are neglected by the cognitivists. Contrary to some fundamental principles of Political Economy, the cognitive capitalism school of thought disregards the relevance of political action and class struggle in the socioeconomic dynamics. Paraphrasing Braga (2009), we can say that this approach has succumbed to the enchantment of technoscientific progress.

In the same vein, McChesney (2013) asserts that the Internet and the so-called digital revolution are not inexorably determined by technology. What determines the structure and the social use of the Web are the decisions taken by society as a whole, considering the struggles and complex conflicts of interest involved, as well as the hegemonic capitalist logic that rules our times.

These arguments provide a preamble to discussing the polarization of knowledge approach, an alternative proposition that avoids some misconceptions of the cognitive capitalism framework. 


\section{POLARIZATION OF KNOWLEDGE}

The idea of polarization of knowledge is an alternative proposition that aims to discuss the role of information and knowledge in the socioeconomic dynamics of the twenty-first century. One of the main principles that guide our point of view is the necessity to avoid the beautified and idealistic perspectives that elide the contradictions of the material bases of social production and social reproduction. Our perspective stresses that the current asymmetric distributions of information and knowledge are increasingly becoming instruments for exploitation and source of socioeconomic inequalities.

The polarization of knowledge approach has two key arguments. The first one is sustained by a historical perspective, according to which knowledge, science, and technology have always been central elements in the struggles between capital and labor.

As history demonstrates, the use of information and knowledge as instruments of domination or emancipation is not a novelty, but it has become increasingly relevant since the early days of the capitalist mode of production, in the 18th century. From its birth to present, capitalism has not manifested any commitment to the universalization of information and knowledge, especially in the workplace. The progressive character of capital, a priori, is not regarded as an educating force. On the contrary, capitalists have always been struggling against workers in order to control the use of information and knowledge in the production process (PAULA, 2011).

In the early days of capitalism, when the ideological elements of the emerging bourgeois mentality were very evident, the decision about which kind of knowledge would be available to workers was explicitly based on restrictive and functional criteria. Workers' literacy should be limited only to the knowledge that was applicable to their labor. Other kinds of knowledge were explicitly considered useless, harmful and dangerous. The words of Mandeville (1732, p.288) illustrate this point of view:

To make the society happy and people easy under the meanest circumstances, it is requisite that great numbers of them should be ignorant as well as poor. Knowledge both enlarges and multiplies our desires [...] The welfare and felicity therefore of every State and Kingdom, require that the knowledge of the working poor should be confined within the verge of their occupations, and never extended (as to things visible) beyond what relates to their calling. The more a shepherd, a plowman or any other peasant knows of the world, and the things that are foreign to his labour or employment, the less fit he will be to go through the fatigues and hardships of it with cheerfulness and content. Reading, writing and arithmetic are very necessary to those whose business requires such qualifications, but where people's livelihood has no dependence on these arts, they are very pernicious to the poor. 
According to Babbage (1832), the division of work in the capitalist production should be conceived aiming at the minimization of learning and skills required in labor processes, in order to increase the child labor and reduce wages. The author, who was a pioneer proponent of the "division of mental labour" (BABBAGE, 1832, p. 191), says:

The facility of acquiring skill in a single process, and the early period of life at which it can be made a source of profit, will induce a greater number of parents to bring up their children to it; and from this circumstance also, the number of workmen being increased, the wages will soon fall (BABBAGE, 1832, pp. 170-171)

Analysing the production process of his times, Marx (1994a [1863], 1994b [1864], 1996 [1867]) describes science and technology as productive powers of capital, dominated and applied by the capitalist class through the relations of production in order to produce value and surplus value. In Marx (1994b, p. 457) words,

Science, the general intellectual product of social development, [...] appears here as directly incorporated into capital [...] and the general development of society, because it is exploited by capital against labour, because it acts as a productive power of capital over against labour, appears as the development of capital.

As a result of the division of labor in manufactures, Marx (1996, p. 366) argues, the alienation of workers from the production process "is completed in modern industry, which makes science a productive force distinct from labour and presses it into the service of capital". In this sense, Marx (1996, p. 367) agrees with Ferguson (1783 [1767], p. 305) according to whom "ignorance is the mother of industry as well as of superstition".

In the early $20^{\text {th }}$ century, the "scientific management" proposed by Taylor (1911), an engineer who was not a Marxist, adopted a radical conception of work control, based on the idea that all decisions in the labor process, especially its subjective factors, should be attributed to managers and directors, but not to workers. In order to achieve this goal, he recommended the collection, registration, and systematization of all knowledge about the production processes that was dominated by the workers. He prescribed that managers should avoid strategies that led them to become dependent on the initiatives and ideas of workers. Therefore, the deskilling of workers is a central element of what Taylor terms "scientific management".

Developing Marx's ideas, Braverman (1998 [1974]) also problematizes the role of information and knowledge in the universe of working relations of the late 20th century. According to him, the mass of workers does not benefit from the fact that production has become more dependent on science and knowledge. As he explains, "the more science is incorporated into the labour process, the less the worker understands the process; the more sophisticated an intellectual product the machine becomes, the less control and comprehension of the machine the worker has" (BRAVERMAN, 1998, p. 295).

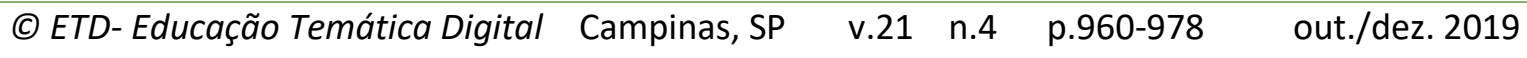


Furthermore, the polarization of knowledge approach has also a second key argument. Information and knowledge have a central role not only in the contradictions between capital and labor, but also in the contradictions within the working class. This argument draws from the ideas of Braverman (1998), Rubin (1972 [1924]), Huws (2001) and Marx (1994b, 1996), as follows.

For Braverman (1998), the detailed division of work that characterizes capitalism is not limited to the division of simple activities on the shop floor but is also present in all the hierarchical levels of the firm. Each phase of the productive process is "divorced, so far as possible, from special knowledge and training and reduced to simple labour" (1998, p. 295). The relatively few workers for whom knowledge and skills are reserved are freed from the obligations of simple work. In extreme cases, a polarization is created which Braverman calls the "general law of the capitalist division of labour". This phenomenon, that "polarizes those whose time is infinitely valuable and those whose time is worth almost nothing", is considered the most powerful and general force acting upon the organization of work (1998, pp. 57-58).

Against the arguments of those who reduce Braverman's conceptions to the simplistic idea of general deskilling, Foster (1994) emphasizes that the author does not affirm that the average skill level of workers would be reduced as a consequence of the capitalist development. In a different direction, Braverman realizes a tendency towards expanding inequalities and knowledge gaps in the working class. As a consequence, a polarization emerges in the working conditions which harms the vast majority and benefits relatively few. In Braverman's terms (1998, pp. 294),

\footnotetext{
Since, with the development of technology and the application to it of the fundamental sciences, the labor processes of society have come to embody a greater amount of scientific knowledge, clearly the "average" scientific, technical, and [...] "skill" content of these labor processes is much greater now than in the past. But this is nothing but a tautology. The question is precisely whether the scientific and "educated" content of labor tends toward averaging, or, on the contrary, toward polarization.
}

As stated by Rubin (1972 [1924]), the uneven access to knowledge and to professional qualification enlarges the contradictions in the universe of labor. In professions that require long qualification periods and have expensive learning costs, obstacles arise with regard to the distribution of works between different economic sectors, as well as barriers to the transference of jobs between different professions. So, the difficulties to be admitted in some occupations that require a high level of skills turn these activities into professional monopolies. 
Contrary to the supposition that new information and communication technologies inexorably tend to emancipate the working class, nowadays there is an increasing gap within the contemporary workforce. Some working processes have become more complex and require multiple qualifications, whereas other ones have been taylorized and require fewer skills. Although new opportunities for workers are arising, there is also evidence of emerging new forms of exclusion and exploitation (HUWS, 2001).

The idea of polarization of knowledge also establishes an interlocution with the concept of the collective laborer adopted by Marx (1994b, 1996). Through the notion of the collective laborer, Marx describes the advanced capitalist production as a complex process that integrates eminently manual activities with intellectual ones, i.e., integrates skilled and unskilled occupations, within a logic that aims to produce value and surplus value. In this context, the single worker ceases to be the real agent of the working process as a whole and is replaced by a socially combined capacity for work. Thus, the labor productivity is due to the combination of manual and intellectual activities executed by different individual workers who constitute the organs of the collective laborer. As Marx (1996, p.510) explains, "in order to labour productively, it is no longer necessary for you to do manual work yourself; enough, if you are an organ of the collective laborer, and perform one of its subordinate functions". For him, the subject of the productive labor is not a homogeneous mass of workers, but a heterogeneous and complex collective laborer constituted by employees with different capacities for work, qualifications, and skills. Some of them have superior education and high technical skills, such as engineers, and others are unskilled and perform mainly manual duties.

Therefore, through the notion of collective laborer, Marx rejects the simplistic dichotomy between intellectual and manual activities that characterizes the cognitive capitalism discourse. Given the growing importance of the contemporary global production chains, when the production processes are fractioned in many phases and allocated in different regions of the world, the Marxian notion of collective laborer becomes even more relevant. In this context, it is essential to consider the complete production processes, wherever its phases are distributed across the globe. As Jeon (2010) correctly points out, production necessarily requires the previous stages of design and project, and design and project can only be realized through execution. In this sense, according to our point of view, there is an unavoidable dialectical unity between the design of an iPhone by a labor aristocracy in Silicon Valley and its production in the horrendous sweatshops of Shenzhen in China.

Although the Marxian concept of collective laborer advocates the integration between skilled and unskilled labor, his dialectical approach also exposes some contradictions among the occupations that compose the collective laborer. His description of the division of labor in the factory system presents the engineers, mechanics, and joiners as a superior class of 
workers that is distinct from the factory operative class: "this is a superior class of workmen, some of them scientifically educated, others brought up to a trade; it is distinct from the factory operative class, and merely aggregated to it" (MARX, 1996, p. 423). The contradictions between manual and intellectual occupations are also presented by Marx in a passage in which he states that, when labor assumes a social scale and the collective laborer emerges, the labor of the hand and of the head "part company and even become deadly foes" (MARX, 1996, p. 509).

In another manuscript, Marx returns to this point and advocates the necessity to overcome the antithesis between mental and physical labor. As he states, in order to build a communist society and cross "the narrow horizon of bourgeois right [...] in its entirely", it would be necessary to vanish the "the enslaving subordination of the individual to the division of labour, and therewith also the antithesis between mental and physical labour" (MARX, 1989, p. 87).

In sum, although both cognitive capitalism and polarization of knowledge approaches aim to apprehend the dynamics of information and knowledge in society, they diverge in some central issues. On the one hand, the cognitivists emphasize the belief in an increasing spread of information and knowledge through sociotechnical networks. According to them, this phenomenon results in crises in contemporary capitalism and foments workers' emancipation. On the other hand, from the polarization of knowledge perspective, knowledge has always been a central element not only in the contradictions between capital and labor, but also in the internal contradictions of the working class. If knowledge can be considered a germ for overcoming inequality and uneven development, the effective realization of this possibility still resides in a distant future and will require political struggles in order to come true.

Given the lack of agreement between the cognitive capitalism and polarization of knowledge approaches, the next section exposes some non-academic discourses. Let's hear the voices from Silicon Valley. 


\section{VOICES FROM SILICON VALLEY 5}

In the second semester of 2012, semi-structured interviews were conducted with representatives of Silicon Valley workers. As a criterion to select the potential interviewees, we decided to contact professionals who have taken part in the board of directors of nongovernmental institutions headquartered in this region, and who also have been involved in the universe of labor within this locus. Our initiatives resulted in seven interviews with unionists and activists that fulfilled these criteria.

The respondents can be briefly presented as follows: (1) the ex-president of a union self-entitled "the Union for the Information Age", which represents more than seven hundred thousand workers, public and private, from the segments of telecommunications, broadcasting, cable TV, news, education and others; (2) a member of the executive board of the San Francisco Labor Council, which represents nineteen unions and more than a hundred thousand workers from the south of San Francisco Bay; (3) a former employee of one of the world's main semiconductor production companies, ex-president of a workers committee of the electronic industry; (4) an engineer, labor activist, which projects are dedicated to the emancipatory use of information and communication technologies, to international integration of workers organizations, as well as to the diffusion of content through Internet and broadcasting; (5) a coordinator of the International Campaign for Responsible Technology, an international network that promotes the accountability in the global electronic industry, evaluating the impact of these activities on the environment and on the working relations; (6) the president of a union of service workers, which belongs to the Service Employees International Union, an international trade union that represents more than two million members in North America; (7) a member of the executive committee of a health services union, and a board member of the Service Employees International Union.

In general terms, despite the diversity of the arguments given by the respondents, all of them emphasize many contradictions that question the capacity of this economic logic to induce the society towards a future with economic opportunities available to most people, less uneven income distribution and improvements on welfare for the less fortunate.

As the respondents report, the offshoring of production plants to Asia and to other low-wage countries abandons an army of unemployed people, since most of those who used to work in the outsourced electronic industry were not incorporated in the production process of the "new economy".

\footnotetext{
${ }^{5}$ The research was submitted to the Brazilian Research Ethics Committee (COEP - Comitê de Ética em Pesquisa). CAAE: 03524012.3.0000.5149.
}

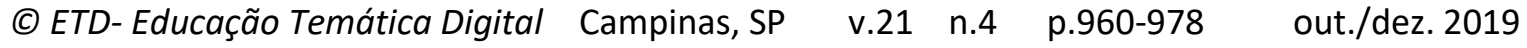


Although the respondents recognize the centrality of information and knowledge in Silicon Valley's ongoing socioeconomic dynamics, they argue that the local education system is suffering a process of severe deterioration. It is said that the pronounced reduction of public funds spent on the education system and its increasing privatization are dramatically damaging it. Accordingly, this situation contributes to the creation of a workforce which is peripherally inserted into the so-called information society, and which is likely to be blocked from intellectual activities considered more economically relevant nowadays. The following speeches exemplify these arguments.

Respondent 5 affirms that the local "educational system is a mess, really. It used to be the best in the world". When he moved to California in 1969, it was "honestly the best public educational system in the country. And it has fallen considerably since then". As he explains, considering that the education system has been defunded, it is harder for people to study in the universities and community colleges. In kindergarten, the classrooms are crammed with children, seriously harming the learning process. The deterioration of the educational system is also emphasized by Respondent 3:

The higher education institutions are being defunded. [...] We have more and more privatized, less and less well-funded education establishments. [...] The educational system underneath the higher educational system is in crisis as well and increasingly unable to produce graduates who will go to those [technology] schools.

Criticizing the ongoing privatization of education in the United States, and specifically in California, Respondent 4 asserts that "the commodification of education in capitalist America and in California is going to be harmful to the development of a thoroughly educated population". He explains:

The schools are falling apart in California. Education is under a massive assault. They are selling off the libraries that used to be in California. They raise the tuition to levels that hinder the students (RESPONDENT 4).

Faced with this situation, Respondent 4 asks: "How are you going to prepare and develop young people to do these jobs if the education is being privatized and they can't pay for education?" His following assertions suggest an answer that points toward a dark future:

\footnotetext{
The ability of the working class and the mass of young people to get in the education is being treated [...] The lack of education, the shutdown of education for working class people, for the mass of people in the United States, is going to be devastating. [Nowadays] there is more money spent in California for prisons than for education (RESPONDENT 4).
}

According to him, this problem "is going to be, over the long run and immediately, very harmful for society and for the development of technology and industry". 
As Respondent 7 alleges, the local education system has a very limited capacity to generate the kind of professionals required by the economy nowadays and it does not "mirror what the new economy is". Given the competition with the production that comes from countries where the workforce is cheap and skilled, the American Government should develop the educational system and sustain the "investment in education and development of the workforce that can continue to develop new ideas and new products". Nonetheless, the respondent says, the United States does not have "enough people creating enough ideas that can really drive our times". The Government has failed "in creating policies that really look at what the jobs of the future are and how to train people to move into those jobs".

Besides the alleged decay of the Silicon Valley's educational system, the discourses of the respondents also reveal another contradiction that questions the emancipatory character of information and knowledge in the local reality. All the respondents emphasize that the regional educational system is extremely uneven. On the one hand, some of the best educational institutions of the United States are located in Silicon Valley. On the other hand, the local poor communities have some of the worst ones. The following quotations present these arguments.

As Respondent 1 says, in addition to the problem of insufficient funding for education, there is also the problem of inequality of the distribution of resources, because the main financial resource that each school receives comes from taxes on the properties where the school is located. This funding system creates enormous disparities: "Palo Alto has very good schools, the best in the country. And then, right across the county, [in the] east side, where a lot of the poor people live, they have some of the worst. And both are in Silicon Valley".

Respondent 5 agrees. In Silicon Valley the educational institutions of some communities are "some of the best in the country", but in other local communities they are "down in the bottom". He explains: "the students who grow up in the wealthy communities get an excellent education and students who grow up in the poor communities have to fight to get even a decent eligible education". This contradiction, he adds, "is directly correlated with the income" and it "got worse over the years, not better" (RESPONDENT 5).

For Respondent 7, the new economy is characterized by high inequality, which represents a serious problem for the United States. He asserts that the best work opportunities in the technology field are unreachable for those who come from the poor communities. Although the children from these neighborhoods have great learning capacity, they will never occupy a place in this labor market due to the place they come from and their precarious education.

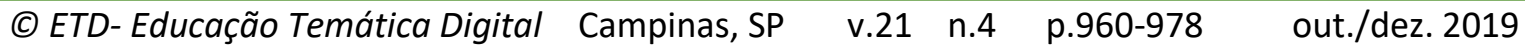


Inequality in this new economy is a big problem in the United States. If you come from a certain sector of society, you will have access to the new jobs, to the new markets. [But] if you don't, your choices are limited. Your choices, instead of going into these fields, are going to the services areas (RESPONDENT 7).

The increasing inequality in the United States is associated with the different origins of the workers. The social and educational experiences of the individuals determine their position in the labor market. He exemplifies:

Where do the Walmart workers come from? Where do the Google workers come from? What is their educational background? The Walmart workers come from poor communities, they have a worse education. They have little or no education. [...] If you go from a school in the suburbs of San Francisco to a school in the suburb of Oakland, it's like night and day. I can tell you where Google is going to be recruiting from. [...] There is a greater chance that somebody who comes from the suburbs of San Francisco can be hired for a Google job than somebody from Oakland. [...] Google is trying to find the best people, the most trained people, and they are not getting trained in Oakland (RESPONDENT 7).

The crisis in the educational system, as Respondent 4 explains, causes the stratification of North American workers, dividing them into highly skilled workers and those who do not have such qualifications. According to him, society does not benefit when it has an oligarchy of a small group of people that is highly recompensed while the second group, which is the majority of people, loses their benefits and see their living conditions deteriorate.

Although the ones who have high skilled jobs are in a secure situation, the service workers, in general, are increasingly more vulnerable. Albeit that they are part of the community, these workers "were left behind in the so-called new economy" (RESPONDENT 1). Concerning the levels of inequality in the Silicon Valley region, respondent 3 has a similar opinion:

The technology industry in the San Francisco Bay area is an unsustainable environment for most people. It is an environment in which few people make a lot of money, but it is not necessarily a sustainable environment, especially for people at the bottom (RESPONDENT 3).

The same respondent asserts that, instead of providing a minimum level of education for the whole population, the North American education system does not educate people equally, but with great disparity, depending on some social aspects such as race, national origin, and economic class.

The educational system is very fragmented and also reflects the existence of social inequalities that we have. So, some people, in this country, do receive an education that prepares them to take a place in an economy in which the skill demands are raising. But an enormous number of people don't. And, generally speaking, the lines between those who do and those who don't are lines of race, national origin and economic class (RESPONDENT 3). 
necessity belongs to the sphere of formal education (immaterials of type 1). Albeit they recognize the necessity of developing a creative and innovative work force (immaterials of type 2), they advocate that this kind of skills are outcomes of educational experiences (immaterials of type 1).

As the speeches of the respondents also suggest, the emancipation of workers by means of a supposed free flow of information and knowledge through cooperative sociotechnical networks is an idealistic conception. For them, the decaying and uneven local educational system does not offer most people the opportunity to take an active part in the economy of the information age, as well as to reap the wealth it generates.

Our analysis suggests that cognitive capitalism has some questionable arguments, such as the characterization of knowledge and skills as a "production instrument that cannot be easily expropriated" and the belief that, currently, "the predator company becomes, in its knowledge, a prey" (MOULIER BOUTANG, 2003, pp. 43-44). Moreover, it does not seem reasonable to portrait the Internet as "the new global common good of the collective intelligence" and it is also questionable if in fact "there is now a dissolving of the traditional dividing lines between capital and labour and between skilled and unskilled labour" (2011a, p.53). These idealized situations are not under way in Silicon Valley, and it is hard to figure out in which locus it is a reality, except for a privileged stratum of society. Such a radical sociotechnical revolution is unlikely to take place spontaneously, by means of a harmonious transition, without contradictions and in the absence of political organization.

In Silicon Valley, the material basis of social reproduction exposes a shocking reality. In 2012, almost $30 \%$ of Silicon Valley's households were living in poverty and below selfsufficiency standards. As revealed by a recent report, "nearly $30 \%$ of all Silicon Valley households do not make enough money to meet their basic needs without public or private, informal assistance". According to the report, "self-sufficiency varies significantly by race/ethnicity; nearly $59 \%(81,245)$ of all Silicon Valley households with a Hispanic or Latino householder live below the Self-Sufficiency Standard" (JOINT VENTURE SILICON VALLEY, 2017, p. 27). Therefore, the local reality is quite different from the discourses that advocate the emergence of a beautified information age. Indeed, we should call our times the age of polarization of knowledge.

It would be better to give attention to some Marxian warnings. Without political action, technological development does not lead to emancipation. The main social and economic transformations do not occur harmonically but through the conscious political intervention of the oppressed classes.

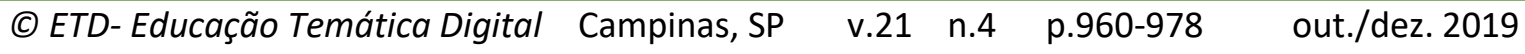




\section{REFERENCES}

AMORIM, Henrique. Trabalho imaterial: Marx e o debate contemporâneo. São Paulo: Annablume. 2009.

ANTUNES, Ricardo. Os sentidos do trabalho. São Paulo: Boitempo. 2009.

BABBAGE, Charles. On the economy of machinery and manufactures. London: Charles Knight. 1832.

BRAGA, Ruy. A vingança de Braverman: o infotaylorismo como contratempo. In: ANTUNES, R.; BRAGA, R. (Org). Infoproletários: degradação real do trabalho virtual. São Paulo: Boitempo. 2009.

BRAVERMAN, Harry. Labour and monopoly capital. New York: Monthly Review, 1998.

FERGUSON, Adam. An essay on the history of civil society. London: T. Cadell, 1783.

FOSTER, John Bellamy. Labor and monopoly capital twenty years after: an introduction. Monthly Review. v. 46, n. 6, pp. 01-13. 1994.

HUWS, Ursula. The making of a cybertariat? Virtual work in a real world. Socialist Register. v. 37, n. 1, pp. 01-23. 2001.

JEON, Heesang. Knowledge economy. In: FINE, B.; SAAD-FILHO, A. (Org.). The Elgar Companion to marxist economics. Cheltenham: Edward Elgar, 2012. p. 180-186.

MANDEVILLE, Bernard. The fable of the bees or private vices, public benefits, Oxford: Clarendon, 1732.

MARX, Karl. Economic works 1857-1861: economic manuscripts of 1857-1858 (Grundrisse). In: MARX, K.; ENGELS, F. Collected Works. London: Lawrence \& Wishart, 1987. v.29

MARX, Karl. Critique of the Gotha programme. In: MARX, K.; ENGELS, F. Collected Works. London: Lawrence \& Wishart, 1989.v.24

MARX, Karl. Economic works 1861-1864. Economic manuscript 1861-1863 (Theories of surplus value). In: MARX, K.; ENGELS, F. Collected Works. London: Lawrence \& Wishart, 1994a. v. 34

MARX, Karl. Economic works 1861-1864 (Chapter Six - Results of the Direct Production Process). In: MARX, K.; ENGELS, F. Collected Works. London: Lawrence \& Wishart, 1994b.v.34

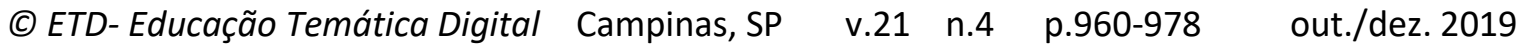


MARX, Karl. Capital - a critique of political economy. In: MARX, K.; ENGELS, F. Collected Works. London: Lawrence \& Wishart. 1996. v.35

McCHESNEY, Robert Waterman. Digital disconnect: how capitalism is turning the internet against democracy. New York: The New Press. 2013.

MOULIER BOUTANG, Yan. O território e as políticas de controle do trabalho no capitalismo cognitivo. In: COCCO, G. (Org.). Capitalismo cognitivo: trabalho, redes e inovação. Rio de Janeiro: DP\&A, 2003.

MOULIER BOUTANG, Yan. Cognitive capitalism. London: Polity, 2011a.

MOULIER BOUTANG, Yan. Wikipolítica e economia das abelhas. Informação, poder e política em uma sociedade digital. In: ALBAGLI, S.; MACIEL, M. L. Informação, conhecimento e poder: mudança tecnológica e inovação social. Rio de Janeiro: Garamond, 2011b.

MOULIER BOUTANG, Yan. Revolução 2.0, comum e polinização. In: COCCO, G.; ALBAGLI, S. Revolução 2.0 e a crise do capitalismo global. Rio de Janeiro: Garamond, 2012.

PAULA, João Antônio. Conference presented. In: SEMINÁRIO A INFORMAÇÃO E O CONHECIMENTO SOB AS LENTES DO MARXISMO, 1., 2011, Belo Horizonte. Anais... Belo Horizonte: ECI/UFMG, 2011.

JOINT VENTURE SILICON VALLEY. Silicon Valley Index 2017. San Jose: Institute for Regional Studies. 2017. Available at: http://www.jointventure.org/download-the-2017-index

RUBIN, Isaak Illich. Essays on Marx's theory of value. Detroit: Black and Red, 1972.

TAYLOR, Frederick Winslow. The principles of scientific management. Nova York: Harper \& Row, 1911.

Grammar review by:

Mr. Kieran Nelson

E-mail: editorkieran@yahoo.com .

\section{ACKNOWLEDGMENTS:}

The research was funded by CAPES (Coordenação de Aperfeiçoamento de Pessoal de Nível Superior), Process Number: BEX 0255/12-2. 